\title{
Atmospheric oxygenation caused by a change in volcanic degassing pressure
}

\author{
Gaillard, Fabrice ${ }^{1, *} ;$ Scaillet, Bruno ${ }^{1}$; Arndt, Nicholas T. ${ }^{2}$ \\ ${ }^{1}$ Institut des Sciences de la Terre d'Orléans, CNRS-INSU/Université d'Orléans/Université de \\ Tours, 1a rue de la Férollerie 45071, Orléans cedex 2, France \\ ${ }^{2}$ ISTerre, Université Joseph Fourier de Grenoble, CNRS, 1381 rue de la Piscine, 38400 Saint \\ Martin d'Hères, France \\ *Email: gaillard@cnrs-orleans.fr
}

The Precambrian history of our planet is marked by two major events: a pulse of continental crust formation at the end of the Archaean eon and a weak oxygenation of the atmosphere (the Great Oxidation Event) that followed, at 2.45 billion years ago. This oxygenation has been linked to the emergence of oxygenic cyanobacteria 1,2 and to changes in the compositions of volcanic gases 3,4 , but not to the composition of erupting lavas-geochemical constraints indicate that the oxidation state of basalts and their mantle sources has remained constant since 3.5 billion years ago $\underline{5,6}$. Here we propose that a decrease in the average pressure of volcanic degassing changed the oxidation state of sulphur in volcanic gases, initiating the modern biogeochemical sulphur cycle and triggering atmospheric oxygenation. Using thermodynamic calculations simulating gas-melt equilibria in erupting magmas, we suggest that mostly submarine Archaean volcanoes produced gases with $\mathrm{SO} 2 / \mathrm{H} 2 \mathrm{~S}<1$ and low sulphur content. Emergence of the continents due to a global decrease in sea level and growth of the continental crust in the late Archaean then led to widespread subaerial volcanism, which in turn yielded gases much richer in sulphur and dominated by SO2. Dissolution of sulphur in sea water and the onset of sulphate reduction processes could then oxidize the atmosphere.

Mass-independent fractionation of sulphur (MIF), quantified as [DELTA] ${ }^{33} \mathrm{~S}$, is commonly recorded in sediments older than 2.45 billion years (Gyr) $\underline{7}$. A proliferation of MIF has been clearly identified between 2.7 and $2.45 \mathrm{Gyr}$, and older spikes are recorded at $>3.4 \mathrm{Gyr}$ (refs $\underline{7}_{-}$ 9). MIF is now widely recognized as the signature of an anoxic atmosphere during the Archaean eon, which allowed the photolysis of atmospheric $\mathrm{SO}_{2}$ conducive to MIF. The abrupt disappearance of MIF at 2.45 Gyr ago is thought to record the Great Oxidation Event - the rise of $\mathrm{O}_{2}$ in the atmosphere that radically changed redox-based biogeochemical processes $\underline{8,9,10}$.

A more complete analysis 11 recently described how complex lithosphere-atmosphere-ocean transfers could have influenced the variation of Archaean MIF, particularly its strong rise between 2.7 and $2.45 \mathrm{Gyr}$ ago, immediately preceding the Great Oxidation Event. A critical trigger of MIF could be the redox ratio of sulphur in volcanic gases $\left(\mathrm{SO}_{2} / \mathrm{H}_{2} \mathrm{~S}\right)$ in an oxygenpoor atmosphere: high volcanic $\mathrm{SO}_{2} / \mathrm{H}_{2} \mathrm{~S}$ produces significant $\mathrm{MIF}$, whereas a low ratio does not 11 . It follows that a change to more-oxidized volcanic gases at the end of the Archaean could have caused the MIF explosion that preceded the Great Oxidation Event $\underline{11}$. The change in the redox state of volcanic gases has been attributed to evolution of the mantle source 
composition $\underline{3}$, but the near invariance through geologic times of $\mathrm{V} / \mathrm{Sc}$ and other redoxsensitive elements indicates that the redox state of the mantle and mantle-derived basalts has remained nearly constant from the middle Archaean to the present 5,6.

Kump and Barley 12 used Holland's redox criteria $\underline{4}$ for volatile degassing to argue that subaerial volcanic gases are more oxidized than submarine ones and proposed that an increasing contribution from subaerial volcanism would have resulted in increasingly oxidizing volcanic emissions. But to define the redox state of Archaean emissions, Kump and Barley 12 used fluids from seafloor hydrothermal vents whose compositions are controlled by redox-sensitive fluid-rock reactions $\underline{13}$ and whose redox state, particularly during the Archaean, is poorly constrained $\underline{4,14}$. Furthermore, a survey of Hawaiian subaerial versus submarine volcanism 15 indicates that submarine lavas are not more reduced than subaerial lavas. Our thermodynamic calculations show that the $\mathrm{SO}_{2} / \mathrm{H}_{2} \mathrm{~S}$ ratio of volcanic gases is only marginally influenced by redox conditions or pre-eruptive volatile contents of the lava, provided they remain within known limits. We show instead that degassing pressure controls this ratio.

Figure 1 reports the amount and speciation of magmatic sulphur in volcanic gases released from oceanic basalt calculated using a gas-melt equilibrium model $\underline{16}$ (see Methods). For similar bulk volatile contents, variations of melt composition within the spectrum of terrestrial mafic magmas have only a minor effect on the composition of gas produced during decompression 16. For simplicity we consider here a Hawaiian tholeiite whose degassing systematics have been well studied $\underline{17}$. The composition of this basalt broadly mimics that of the tholeiites that dominate Archaean sequences. Figure 1 shows the effect of pressure and of the relative concentrations of pre-eruptive volatiles ( $\mathrm{S}, \mathrm{H}$ and $\mathrm{C}$ ) on the amount and speciation of sulphur in volcanic gases. The black curves show degassing paths for an average basaltic source (oxygen fugacity, FMQ - 0.5 (0.5 log unit more reducing than the oxygen fugacity of the fayalite magnetite quartz (FMQ) buffer assemblage; $0.5 \mathrm{wt} \% \mathrm{H}_{2} \mathrm{O} ; 0.3 \mathrm{wt} \% \mathrm{CO}_{2} ; 0.15$ wt $\% \mathrm{~S})$. The total amount of sulphur in volcanic gases $\left(\mathrm{H}_{2} \mathrm{~S}+\mathrm{S}_{2}+\mathrm{SO}_{2}\right)$ increases with decreasing pressure. At pressures exceeding 100 bar, the total degassed sulphur is relatively low, around $0.05 \mathrm{wt} \%$ for normally hydrated basalts. It reaches a maximum value at atmospheric pressure, where the degassed $\mathrm{S}$ species is in the range $0.17-0.25 \mathrm{wt} \%$. The portion of degassed $\mathrm{H}_{2} \mathrm{~S}$ shows a maximum of $0.05-0.06 \mathrm{wt} \%$ at moderately low pressures in the range 20-100 bar. At still lower pressures, the quantity of $\mathrm{H}_{2} \mathrm{~S}$ dramatically decreases and $\mathrm{SO}_{2}$ becomes the dominant species. At pressures higher than 20 bar, the average $\mathrm{SO}_{2} / \mathrm{H}_{2} \mathrm{~S}$ ratio is less than 0.5 , reaching values of 2 to 8 at atmospheric pressure. Figure 1 therefore conveys two important factors, both independent of the source characteristics of the magma: (1) the total amount of degassed sulphur increases with decreasing pressure, and (2) at pressures exceeding a few tens of bar, sulphur is degassed as $\mathrm{H}_{2} \mathrm{~S}$, whereas at atmospheric pressure, $\mathrm{SO}_{2}$ is the dominant species.

Figure 2 shows how the overall composition of the gas phase varies as a function of pressure. $\mathrm{SO}_{2}$ replaces $\mathrm{H}_{2} \mathrm{~S}$ as the dominant sulphur species at about 5 bar (Fig. 1 also shows that the pressure crossover ranges from 3 to 200 bar). The molar $\mathrm{CO}_{2} / \mathrm{H}_{2} \mathrm{O}$ ratio also changes: deep degassing produces $\mathrm{CO}_{2}$-rich gases, whereas surface degassing produces water-rich gases. The $\mathrm{H}_{2} \mathrm{~S}-\mathrm{SO}_{2}$ shift is not directly related to the $\mathrm{CO}_{2} / \mathrm{H}_{2} \mathrm{O}$ ratio but is essentially controlled by the following reaction, which occurs in the gas phase as pressure decreases (Methods): 
Owing to the mole difference between reactants and products, a decrease in pressure displaces reaction (1) to the right. The shallow production of $\mathrm{SO}_{2}$ and deep degassing of $\mathrm{H}_{2} \mathrm{~S}$ anticipated from theoretical considerations is confirmed by field volcanic gas studies $\underline{16,17,18}$. The production of $\mathrm{SO}_{2}$ in the gas is accompanied by formation of $\mathrm{H}_{2}$

$$
\mathrm{H}_{2} \mathrm{~S}+2 \mathrm{H}_{2} \mathrm{O} \rightarrow \mathrm{SO}_{2}+3 \mathrm{H}_{2}
$$

reaching $6 \mathrm{~mol} \%$ at atmospheric pressure. Figures 1 and 2 show unequivocally that the distribution of oxygen between water and sulphur species is primarily controlled by the pressure of degassing, and that neither the redox state of the magma source nor abundance of pre-eruptive volatiles have a significant effect. Hence, changes in the source processes such as the initiation of subduction-related volcanism should not overwhelm the fundamental pressure control on the composition of volcanic gases.

IF records in Archaean sedimentary sulphides show that [DELTA ${ }^{33} \mathrm{~S}$ remained moderate and lower than 4\% in the period 3.9-3.5 Gyr ago and lower than $2 \%$ in the period 3.5-2.7 Gyr ago $7,8,9$. This must indicate volcanic emissions with low to moderate $\mathrm{SO}_{2} / \mathrm{H}_{2} \mathrm{~S}$ (ref. 11), a characteristic that we attribute to volcanic degassing predominantly at pressures of at least a few tens of bars (Figs 1 and 2). Conversely, the strong MIF excursion at 2.7-2.5 Gyr ago records transient volcanic emissions with high $\mathrm{SO}_{2} / \mathrm{H}_{2} \mathrm{~S}$ that can be obtained only through degassing at atmospheric pressure.

The Archaean tectonic style is debated. Higher mantle temperatures $\underline{19}$ are thought to have had two effects. First, they led to the formation of thicker oceanic crust because of enhanced melting at mid-ocean ridges 20 . Second, ocean volumes were larger because enhanced degassing in upwelling zones, and more complete and shallower dehydration of subducting oceanic crust, resulted in a larger proportion of the total water budget being at the surface 21,22. Higher temperatures in the continental crust (because of higher contents of radioactive heat-producing isotopes 23 ) reduced the strength of the continental lithosphere and resulted in subdued topography. Therefore, we attribute the decrease in venting pressure from about 100 to 1 bar at the Archaean-Proterozoic transition to a global decrease in sea level accompanying the growth of the continental crust, amplified by a decrease in ocean volume. Near-global submergence of the continents prevailed through most of the Archaean 24,25 and almost all the volcanoes were submarine, as observed in ancient terrains 24 . At specific times through the Precambrian era, however, the rate of crustal growth and/or continent assembly accelerated dramatically $\underline{26}$. The largest of these events, at $2.7 \mathrm{Gyr}$ ago, was accompanied by a major MIF spike. We propose that this spike, and perhaps the earlier one around 3.5 Gyr ago, resulted from the transient emergence of exposed land from the global ocean. Subaerial volcanism then emitted $\mathrm{SO}_{2}$-dominated gas into an oxygen-poor atmosphere. The importance of such a transition in the eruptive style has been suggested before 12 , but our analysis enables a quantitative description of its biogeochemical impacts. Typical compositions of volcanic gases as a function of pressure of gas venting and as a function of emerged land area are given in Supplementary Tables 1 and 2 and in Supplementary Fig. 1.

We assume that during most of the Archaean, the continents were covered by more than 100 $\mathrm{m}$ of water, with the consequence that volcanic gases contained little sulphur and were 
dominated by $\mathrm{H}_{2} \mathrm{~S}$, with $\mathrm{SO}_{2} / \mathrm{H}_{2} \mathrm{~S}<1$ (Fig. 1). Following emergence of the continents, volcanic emissions contained up to five times more sulphur and $\mathrm{SO}_{2}$ was the dominant species with typical $\mathrm{SO}_{2} / \mathrm{H}_{2} \mathrm{~S}$ ratios in the range 2-9. Archaean oceans are believed to have been almost sulphate-free, in contrast to present-day sulphate-rich sea water $\underline{27,28}\left(28 \mathrm{mmol} \mathrm{kg}{ }^{-1}\right)$. The absence of oxygen in the Archaean atmosphere prevented oxidative alteration of continental pyrite, which is generally put forward to assert the rarity of sulphate ions in contemporaneous seas 27,28 . However, an absence of sulphate in sea water precludes the sulphate-reduction 28 processes, which in turn could dramatically affect atmosphere oxygenation. Bacterial sulphate reduction produces an overall gain in atmospheric $\mathrm{O}_{2}$ (ref. 28), which is, however, related to photosynthetic activity. But thermochemical sulphate reduction, mainly related to hydrothermal activity $\underline{13}$, must have influenced oxygen balance: in the absence of thermochemical sulphate-reduction processes, $\mathrm{O}_{2}$ provided by photosynthetic bacteria was consumed by ferrous iron dissolved in the ocean $\underline{1,14}$ and by hydrothermal smokers injecting strongly reduced gases $\underline{4,14}$ (Supplementary Fig. 2). Thermochemical sulphate reduction immobilized ferrous iron emitted by hydrothermal smokers to form pyrite $\underline{13,14}$, and decreased the overall reducing capacity of hydrothermal fluids $\underline{4}$. The onset of thermochemical sulphate reduction must therefore have positively affected atmospheric oxygenation (Supplementary Fig. 3).

Our calculations suggest that submarine volcanism, dominant through most of the Archaean, produced low-sulphur gases of essentially $\mathrm{H}_{2} \mathrm{~S}$, which is much less soluble in surface waters than $\mathrm{SO}_{2} 27,28$. When subaerial volcanic degassing became important in the late Archaean, it injected $\mathrm{SO}_{2}$ that produced sulphate in sea water by disproportionation upon cooling in the atmosphere $\underline{4}$ or by reduction by ferric iron in shallow waters $\underline{11}$. Consistent with recent observations $\underline{29}$, we propose that incorporation of sulphate into sea water preceded the Great Oxidation Event as subaerial volcanism became volumetrically important and then activated sulphate-reduction processes that must have resulted in $\mathrm{O}_{2}$ enrichment of the $\mathrm{O}_{2}$-low Archaean exosphere. Furthermore, subaerial volcanic gases are much richer in $\mathrm{H}_{2}$ than submarine emissions (Fig. 2) and this must have enhanced hydrogen escape, a process that atmospheric models describe as an oxygenation factor for the atmosphere $\underline{10,30}$.

Figure 3 illustrates the sequence of events that may explain the relationships between MIF, volcanic gases, emergence of continents and oxygen rise during the late Archaean-early Proterozoic transition. The proposed sequence is: (1) submarine volcanism through most of the Archaean, yielding volcanic emissions with low $\mathrm{SO}_{2} / \mathrm{H}_{2} \mathrm{~S}$ and moderate MIF in sediments, (2) emergence of continents in the late Archaean, which produced abundant but irregularly distributed volcanic $\mathrm{SO}_{2}$ and led to the MIF proliferation recorded in sediments at 2.7-2.5 Gyr, (3) decomposition/oxidation of atmospheric $\mathrm{SO}_{2}$ in sulphate, which dissolved into the oceans, (4) the start of sulphate-reduction processes, resulting in the net gain in $\mathrm{O}_{2}$, coupled with enhanced hydrogen escape, which finally led to (5) oxygenation of the atmosphere well after the appearance of oxygenic cyanobacteria 1 . Once oxygen was present in abundance in the atmosphere, the MIF of sedimentary sulphur disappeared.

The major finding of our study is that the sulphur MIF record of the Archaean can be explained by a change in composition of volcanic gases that facilitated oxygenation of the atmosphere. Changes in magma source processes are not the driving force; rather, the increasing $\mathrm{SO}_{2} / \mathrm{H}_{2} \mathrm{~S}$ ratio of volcanic gases is explained by the increasing subaerial volcanism accompanying the emergence of continents. This, together with the rapid crustal growth that is globally observed at $2.7 \mathrm{Gyr}$, implies a change in geodynamic style that is most probably 
due to a cooler mantle and crust. A similar pulse of crustal growth at 3.4 Gyr ago, though smaller, may have caused the emergence of the continents and triggered the earlier MIF event.

\section{Methods Summary}

Gas-melt equilibria have been simulated using a code detailed elsewhere $\underline{16}$. At each pressure step from 2,000 to $1 \mathrm{bar}$, we simultaneously solve the gas-melt solubility equations for $\mathrm{H}_{2} \mathrm{O}-\mathrm{OH}^{-}, \mathrm{CO}_{2}-\mathrm{CO}_{3}{ }^{2-}, \mathrm{S}_{2}-\mathrm{S}^{2-}$ and the gas-gas redox equilibria involving $\mathrm{H}_{2}-\mathrm{H}_{2} \mathrm{O}, \mathrm{CH}_{4}-$ $\mathrm{CO}-\mathrm{CO}_{2}, \mathrm{H}_{2} \mathrm{~S}-\mathrm{S}_{2}-\mathrm{SO}_{2}$, under the requirement that the amounts of $\mathrm{H}, \mathrm{S}, \mathrm{O}$ and $\mathrm{C}$ remain constant in the magma (gas + melt). The iron redox state in the melt is also computed at each step. Each of these equilibrium constants has been experimentally investigated and our model combines the existing experimental data for each equilibrium into a multi-component system. Oxygen fugacity was allowed to vary in response to the various redox equilibria that occur essentially in the gas phase $\underline{16}$, maintaining as constant the bulk oxygen/cation ratio of the system (system closed to oxygen). A system open to oxygen would not, however, change our conclusion that $\mathrm{H}_{2} \mathrm{~S}$ is dominant in the range 10-200 bar as opposed to $\mathrm{SO}_{2}$ at atmospheric pressure. The $\mathrm{SO}_{2} / \mathrm{H}_{2} \mathrm{~S}$ changes are primarily due to pressure changes, as illustrated in Figs 1 $\underline{\text { and } 2}$. Field measurements on active volcanoes $\underline{17,18}$ are consistent with our predictions. The redox state and the relative volatile abundances in the source magma are second-order parameters, implying no specific influence of the source region. We therefore assumed a common source, unlike previous studies $\underline{11,12}$.

\section{METHOD}

Following ref. $\underline{16}$, the mole fraction of the different gas species is calculated from the thermodynamic constants of the reactions occurring in the system $\mathrm{C}-\mathrm{H}-\mathrm{S}-\mathrm{O}$ at magmatic pressure and temperature $\underline{31}$.

The homogeneous equilibria in the gas phase are

In addition, the following melt-gas equilibria are taken into account using thermodynamic data from ref. $\underline{32}$ for water and carbon dioxide, and ref. $\underline{33}$ for sulphur and ref. $\underline{34}$ for $\mathrm{H}_{2}$ : The iron redox ratio in the melt is computed following ref. $\underline{35}$ as

Each of the equilibrium constants (reactions (2) to (10)) has been combined in the multicomponent $\mathrm{C}-\mathrm{O}-\mathrm{H}-\mathrm{S}$ system. The overall uncertainties in calculated gas compositions are $10 \%-15 \%$. These uncertainties are mainly inherited from the experimental calibration of $\mathrm{C}-$ $\mathrm{O}-\mathrm{H}-\mathrm{S}$ species solubility $31,32,33,34$. During degassing, the bulk mass fractions of the different volatile components $(\mathrm{H}, \mathrm{S}, \mathrm{C}, \mathrm{O})$ are kept constant and gas-melt, gas-gas and meltmelt equilibria are simultaneously solved to derive the gas species abundances at each pressure step (from 2,000 to 1 bar). The number of pressure steps imposed in the calculations has no effect on the results because thermodynamic equilibrium does not depend on the pressure-temperature path but only on the final pressure and temperature considered. The initial abundance of $\mathrm{C}-\mathrm{O}-\mathrm{H}-\mathrm{S}$ components is fixed at 2,000 bar, which sets the amount of dissolved volatiles and both quantity and composition of the coexisting gas fraction. The system was computed as a system closed to oxygen $\underline{16,36}$ but the differences between open or closed system conditions remain negligible.

$\mathrm{CO}^{\text {[gas] }}+1 / 2 \mathrm{O}_{2}=\mathrm{CO}_{2}^{\text {[gas] }}$ 


$$
\begin{aligned}
& \mathrm{H}_{2}^{\text {[gas] }}+1 / 2 \mathrm{O}_{2}=\mathrm{H}_{2} \mathrm{O}^{\text {[gas] }} \\
& \mathrm{CH}_{4}{ }^{\text {[gas }]}+\mathrm{O}_{2}=\mathrm{CO}_{2}{ }^{\text {[gas }]}+2 \mathrm{H}_{2} \mathrm{O}^{\text {[gas }]} \\
& 1 / 2 \mathrm{~S}_{2}^{\text {[gas] }}+\mathrm{O}_{2}=\mathrm{SO}_{2}^{\text {[gas] }} \\
& 1 / 2 \mathrm{~S}_{2}^{\text {[gas] }}+\mathrm{H}_{2} \mathrm{O}^{\text {[gas] }}=\mathrm{H}_{2} \mathrm{~S}^{\text {[gas] }}+1 / 2 \mathrm{O}_{2} \\
& \mathrm{H}_{2} \mathrm{O}^{[\text {gas }]}+\mathrm{O}^{2-[\text { melt }]}=2 \mathrm{OH}^{-[\text {melt }]} \\
& \mathrm{CO}_{2}{ }^{\text {[gas] }}+\mathrm{O}^{2-[\text { melt }]}=\mathrm{CO}_{3}{ }^{2-[\text { melt }]} \\
& \mathrm{S}_{2}^{[\text {gas }]}+2 \mathrm{O}^{2-[\text { melt }]}=\mathrm{O}_{2}+2 \mathrm{~S}^{2-[\text { melt }]} \\
& \mathrm{H}_{2}{ }^{\text {[gas] }}=\mathrm{H}_{2}{ }^{\text {[melt }]}
\end{aligned}
$$

Upon decompression, because volatile solubilities in the melt decreases, the gas fraction increases and its composition changes, being enriched in highly volatile species $\left(\mathrm{CO}_{2}\right)$ at high pressure and progressively diluted by less volatile species $\left(\mathrm{H}_{2} \mathrm{O}\right.$ and sulphur species) with decreasing pressure. Sulphur species display a critical change at low pressure: $\mathrm{SO}_{2}$, nearly absent at elevated degassing pressures, dominates at 1 bar over $\mathrm{H}_{2} \mathrm{~S}$ and $\mathrm{S}_{2}$. The stoichiometry of those changes follows the reactions

for gas-gas equilibria and the reaction

for melt-gas equilibria.

In reactions (12) and (13), the right-hand side involves a higher mole number and is therefore favoured by decreasing pressure. In reaction (14), sulphur degassing as $\mathrm{SO}_{2}$ at low pressure implies a reduction of ferric into ferrous iron, consistent with geochemical observations $\underline{15}$. The importance of reaction (14), which may induce a decrease in melt oxygen fugacity, is, however, limited by the kinetics of melt reduction $\underline{37}$. This kinetics delay between reactions (12) and (13) and reaction (14), which we do not take into account, allows the gas $\mathrm{SO}_{2} / \mathrm{H}_{2} \mathrm{~S}$ ratio to be higher than predicted in Figs 1 and 2, potentially exceeding 10 at 1 bar. The thermochemistry of high-temperature gas-melt volcanic systems therefore offer the most likely explanation of variation in sulphur MIF observed during the Archaean.

$$
\begin{aligned}
& \mathrm{H}_{2} \mathrm{~S}+2 \mathrm{H}_{2} \mathrm{O} \rightarrow \mathrm{SO}_{2}+3 \mathrm{H}_{2} \\
& \mathrm{~S}_{2}+4 \mathrm{H}_{2} \mathrm{O} \rightarrow 2 \mathrm{SO}_{2}+4 \mathrm{H}_{2} \\
& \mathrm{~S}^{2-[\text { melt }]}+3 \mathrm{Fe}_{2} \mathrm{O}_{3}{ }^{\text {[melt }]} \rightarrow \mathrm{SO}_{2}+6 \mathrm{FeO}^{[\text {melt }]}+\mathrm{O}^{2-[\text { melt }]}
\end{aligned}
$$


Acknowledgements

We thank T. Lyons, D. Canil and N. Sleep for comments. We acknowledge support by INSUPNP and the ANR (grants ANR-10-BLAN-60301 and ANR-10-BLAN-62101).

1. Buick, R. When did oxygenic photosynthesis evolve? Phil. Trans. R. Soc. Lond. B 363, 2731-2743 (2008)

2. Campbell, I. H. \& Allen, C. M. Formation of supercontinents linked to increases in atmospheric oxygen. Nature Geosci. 1, 554-558 (2008)

3. Kasting, J. F., Eggler, D. H. \& Raeburn, S. P. Mantle redox evolution and the oxidation state of the Archean atmosphere. J. Geol. 101, 245-257 (1993)

4. Holland, H. D. Volcanic gases, black smokers, and the Great Oxidation Event. Geochim. Cosmochim. Acta 66, 3811-3826 (2002)

5. Canil, D. Vanadium in peridotites, mantle redox and tectonic environments: Archean to present. Earth Planet. Sci. Lett. 195, 75-90 (2002)

6. Li, Z. X. A. \& Lee, C. T. A. The constancy of upper mantle $\mathrm{fO}_{2}$ through time inferred from V/Sc ratios in basalts. Earth Planet. Sci. Lett. 228, 483-493 (2004)

7. Farquhar, J. et al. Isotopic evidence for Mesoarchaean anoxia and changing atmospheric sulphur chemistry. Nature 449, 706-709 (2007)

8. Canfield, D. E., Habicht, K. S. \& Thamdrup, B. The Archean sulphur cycle and the early history of atmospheric oxygen. Nature 288, 658-661 (2000)

9. Farquhar, J., Bao, H. \& Thiemans, M. Atmospheric influence of Earth's earliest sulfur cycle. Science $289,756-758$ (2000)

10. Zahnle, K. J., Claire, M. W. \& Catling, D. C. The loss of mass-independent fractionation in sulfur due to a Paleoproterozoic collapse of atmospheric methane. Geobiology 4, 271-283 (2006)

11. Halevy, I., Johnston, D. T. \& Schrag, D. P. Explaining the structure of the Archean massindependent sulfur isotope record. Science 329, 204-207 (2010)

12. Kump, L. R. \& Barley, M. E. Increased subaerial volcanism and the rise of atmospheric oxygen 2.5 billion years ago. Nature 448, 1033-1036 (2007) 
13. Butterfield, D. A. et al. Seafloor eruptions and evolution of hydrothermal fluid chemistry. Phil. Trans. R. Soc. Lond. A 355, 369-386 (1997)

14. Kump, L. R. \& Seyfried, W. E. Hydrothermal Fe fluxes during the Precambrian: effect of low oceanic sulfate concentrations and low hydrostatic pressure on the composition of black smokers. Earth Planet. Sci. Lett. 235, 654-662 (2005)

15. Carmichael, I. S. E. The redox states of basic and silicic magmas: a reflection of their source regions? Contrib. Mineral. Petrol. 106, 129-141 (1991)

16. Gaillard, F. \& Scaillet, B. The sulfur content of volcanic gases on Mars. Earth Planet. Sci. Lett. 279, 34-43 (2009)

17. Oppenheimer, C., Scaillet, B. \& Martin, R. S. Sulfur degassing from volcanoes: source conditions, surveillance, plume chemistry and Earth system impacts. Rev. Mineral. Geochem. 73, 363-421 (2011)

18. Aiuppa, A. et al. $\mathrm{H}_{2} \mathrm{~S}$ fluxes from Mt. Etna, Stromboli and Vulcano (Italy) and implications for the global volcanic sulfur budget. Geochim. Cosmochim. Acta 69, 1861$1871(2005)$

19. Bickle, M. J. Heat loss from the Earth: a constraint on Archaean tectonics from the relation between geothermal gradients and the rate of heat production. Earth Planet. Sci. Lett. 40, 301-315 (1978)

20. Sleep, N. H. \& Windley, B. F. Archean plate tectonics - constraints and inferences. J. Geol. 90, 363-379 (1982)

21. Kasting, J. F. \& Holm, N. G. What determines the volume of the oceans. Earth Planet. Sci. Lett. 109, 507-515 (1992)

22. Bounama, C., Franck, S. \& von Bloh, W. The fate of the Earth's ocean. Hydrol. Earth Syst. Sci. 5, 569-575 (2001)

23. Sandiford, M. \& McLaren, S. in Evolution and Differentiation of the Continental Crust (eds Brown, M. \& Rushmer, T) 67-92 (Cambridge University Press, 2006)

24. Arndt, N. T. Why was flood volcanism on submerged continental platforms so common in the Precambrian? Precambr. Res. 97, 155-164 (1998)

25. Flament, N., Coltice, N. \& Rey, P. F. A case for late-Archaean continental emergence from thermal evolution models and hypsometry. Earth Planet. Sci. Lett. 275, 326-336 (2008)

26. Taylor, S. R. \& McLennan, S. M. The Continental Crust: Its Composition and Evolution 1-312 (Blackwell, 1985) 
27. Habicht, K. S., Gade, M., Thamdrup, B., Berg, P. \& Canfield, D. E. Calibration of sulfate levels in the Archean ocean. Science 298, 2372-2374 (2002)

28. Lyons, T. W. \& Gill, B. C. Ancient sulfur cycling and oxygenation of the early biosphere. Elements 6, 93-99 (2010)

29. Scott, C. T. et al. Late Archean euxinic conditions before the rise of atmospheric oxygen. Geology 39, 119-122 (2011)

30. Claire, M. W., Catling, D. C. \& Zahnle, K. J. Biogeochemical modelling of the rise in atmospheric oxygen. Geobiology 4, 239-269 (2006)

31. Shi, P. F. \& Saxena, S. K. Thermodynamic modelling of the C-H-O-S fluid system. Am. Mineral. 77, 1038-1049 (1992)

32. Morizet, Y., Paris, M., Gaillard, F. \& Scaillet, B. C-O-H fluid solubility in haplobasalt under reducing conditions: an experimental study. Chem. Geol. 279, 1-16 (2010)

33. O'Neill, H. S. C. \& Mavrogenes, J. The sulfide saturation capacity and the sulphur content at sulfide saturation of silicate melts at $1400{ }^{\circ} \mathrm{C}$ and 1 bar. J. Petrol. 43, 1049-1087 (2002)

34. Gaillard, F., Schmidt, B. C., Mackwell, S. \& McCammon, C. Rate of hydrogen-iron redox exchange in silicate melts and glasses. Geochim. Cosmochim. Acta 67, 2427-2441 (2003)

35. Kress, V. C. \& Carmichael, I. S. E. The compressibility of silicate liquids containing $\mathrm{Fe}_{2} \mathrm{O}_{3}$ and the effect of composition, temperature, oxygen fugacity and pressure on their redox states. Contrib. Mineral. Petrol. 108, 82-92 (1991)

36. Burgisser, A. \& Scaillet, B. Redox evolution of degassing magma rising to the surface. Nature 445, 194-197 (2007)

37. Pommier, A., Gaillard, F. \& Pichavant, M. Time-dependent changes of the electrical conductivity of basaltic melts with redox state. Geochim. Cosmochim. Acta 74, 1653-1671 (2010) 


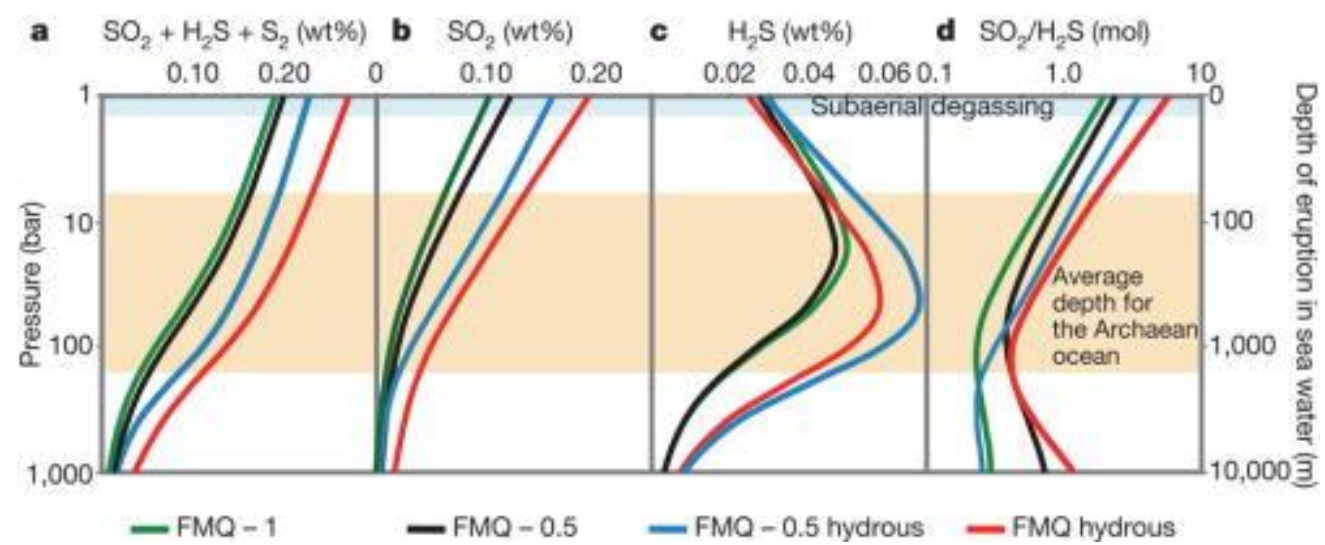

Figure 1 | Calculated sulphur content and speciation in volcanic gases as a function of pressure. We considered a basaltic magma containing $\mathrm{H}_{2} \mathrm{O}=0.5 \mathrm{wt} \%, \mathrm{CO}_{2}=0.3 \mathrm{wt} \%, \mathrm{~S}=0.15$ wt\% (black curves). Nevertheless, we varied the total water content ('hydrous' means 1 wt $\% \mathrm{H}_{2} \mathrm{O}$ ) and the redox state (FMQ - 1 to FMQ), a range that encompasses conditions of subduction-related basalts and oceanic basalts, to illustrate that the influence of such variations is negligible in comparison to the effect of degassing pressure. $a$, Total amount of degassed sulphur species $\left(\mathrm{H}_{2} \mathrm{~S}+\mathrm{S}_{2}+\mathrm{SO}_{2}\right)$ expressed as weight per cent of the basaltic magma. $b$, Sulphur emitted as $\mathrm{SO}_{2}$ expressed as weight per cent of the basaltic magma. c, Sulphur emitted as $\mathrm{H}_{2} \mathrm{~S}$ expressed in weight per cent of the basaltic magma. $d$, Molar $\mathrm{SO}_{2} / \mathrm{H}_{2} \mathrm{~S}$ ratio of volcanic gases. All calculations are performed at $1,300^{\circ} \mathrm{C}$. 


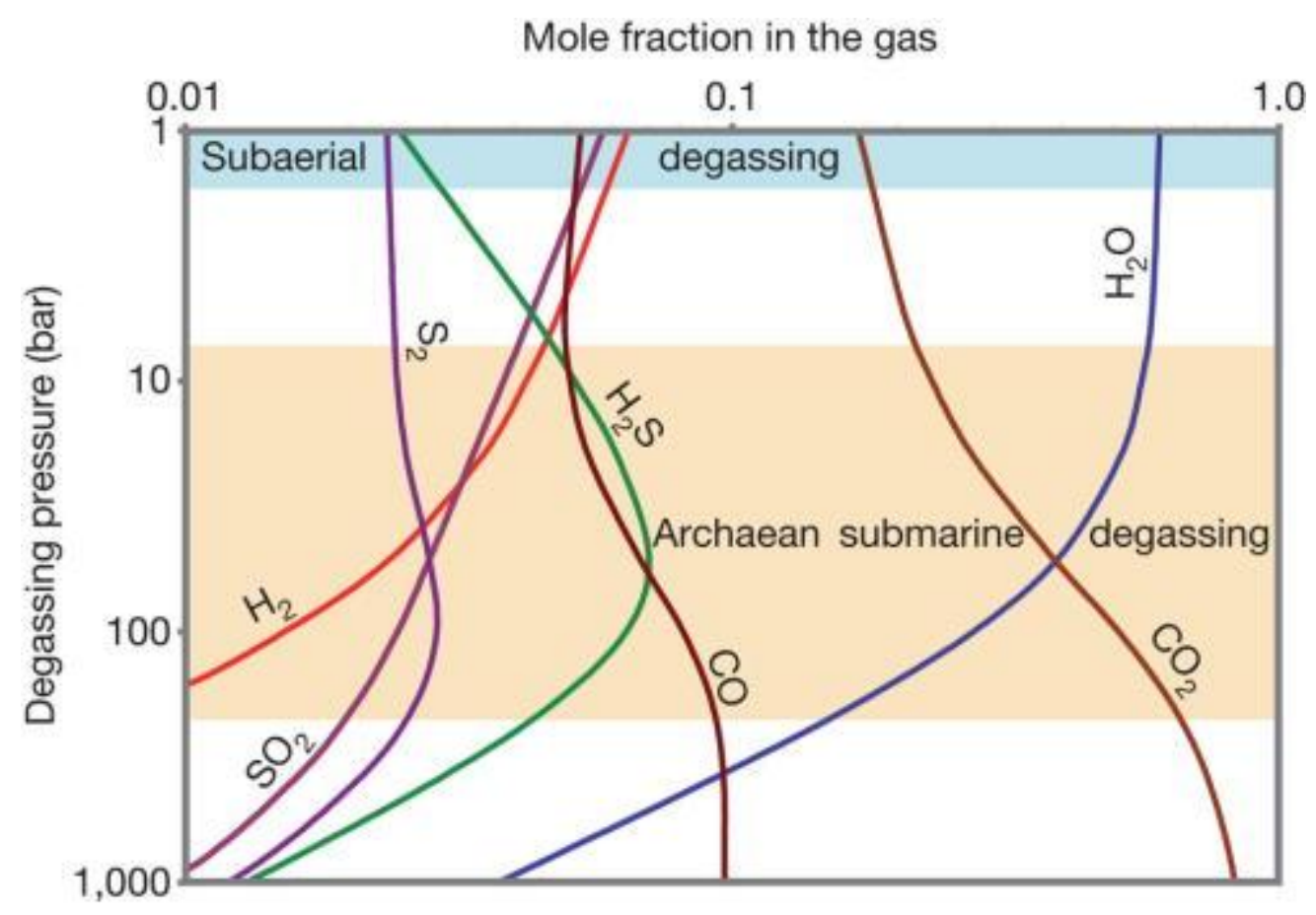

Figure 2 | Calculated compositions in mole fractions of volcanic gases as a function of pressure. The case corresponding to the black lines in Fig. 1 is shown. The inversion $\mathrm{H}_{2} \mathrm{~S}-\mathrm{SO}_{2}$ occurs at a pressure around 10 bar. Submarine degassing produces on average a $\mathrm{SO}_{2} / \mathrm{H}_{2} \mathrm{~S}$ ratio of 0.4 , with $\mathrm{CO}_{2}$ being the dominant gas species. Subaerial degassing yields more $\mathrm{H}_{2} \mathrm{O}$ than $\mathrm{CO}_{2}$, and $\mathrm{SO}_{2}$ is at least three times more abundant than $\mathrm{H}_{2} \mathrm{~S}$. $\mathrm{H}_{2}$ constitutes $6 \%$ of the gas emitted at atmospheric pressure. All calculations are performed at $1,300^{\circ} \mathrm{C}$. 


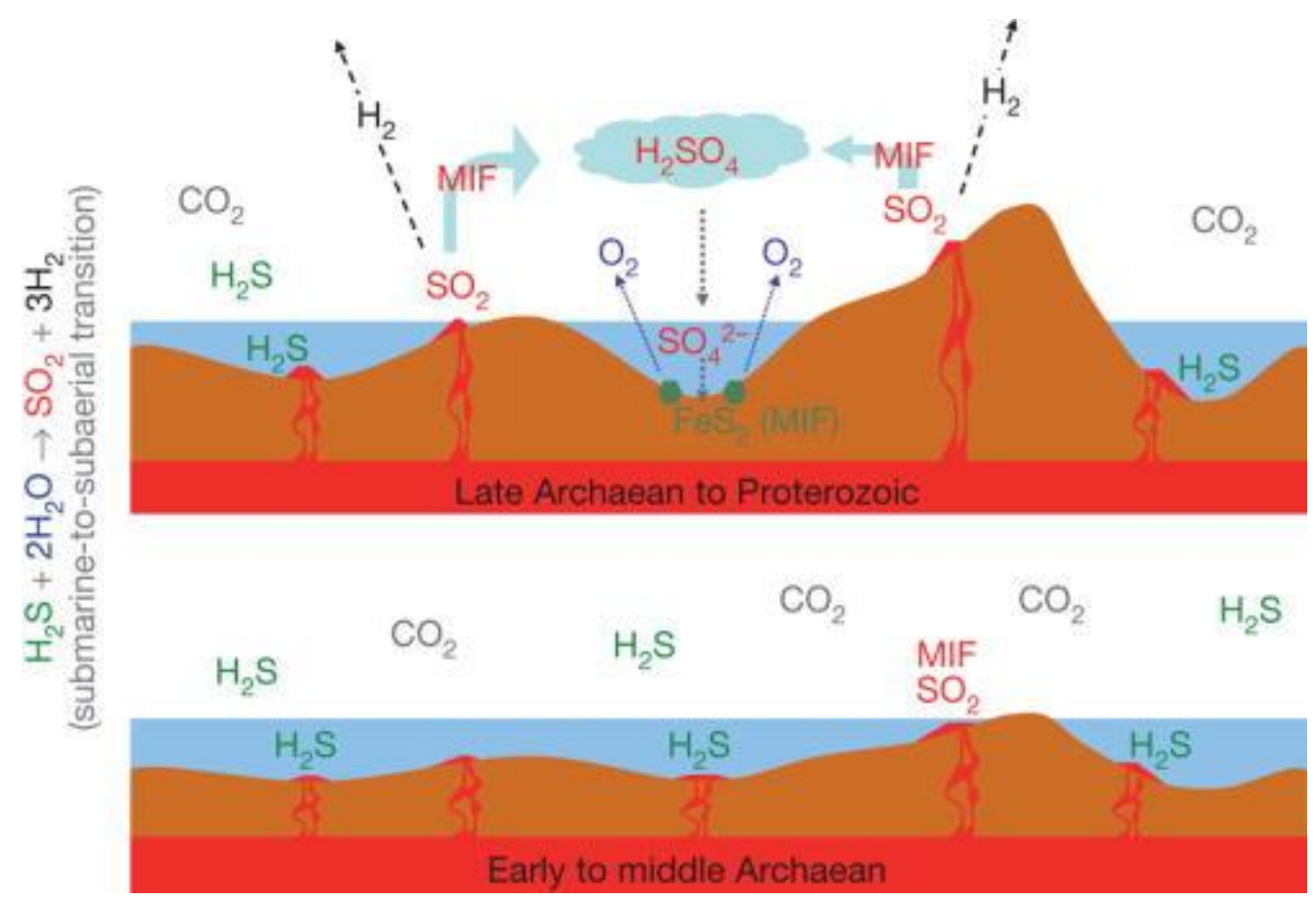

Figure 3 | Schematic illustrating the relationships between pressure of volcanic degassing and redox biogeochemical cycling. In detail, we illustrate sea level changes, continent emergence, changes in composition of volcanic gases, and the overall impact on redox biogeochemistry and oxygen rise and the Archaean-Proterozoic boundary. The lower panel shows the early to middle Archaean with large ocean volume and subdued topography, implying that most of the Earth was submerged and volcanism was predominantly submarine. Such a configuration produced volcanic gases with low $\mathrm{SO}_{2} / \mathrm{H}_{2} \mathrm{~S}$ ratios, and moderate sulphur MIF. In contrast, in the late Archaean, shown in the top panel, continent emergence permitted the widespread occurrence of subaerial volcanism, characterized by gases with higher $\mathrm{SO}_{2} / \mathrm{H}_{2} \mathrm{~S}$ ratios and $\mathrm{H}_{2}$ contents. Such a configuration explains the proliferation of sulphur MIF in the period 2.7-2.5 Gyr. Increasing $\mathrm{SO}_{2}$ contents in the atmosphere triggered an increase in seawater sulphate content, which enhanced sulphate reduction processes (Supplementary Figs 2 and 3). This, coupled with higher $\mathrm{H}_{2}$ escape, resulted in a net gain in atmospheric $\mathrm{O}_{2}$. The atmospheric oxygen rise, nevertheless, did not occur in the late Archaean but in the early Proterozoic. 